\title{
Comparative analysis of physical performance and fishing efficiency between biodegradable PLA gill net and conventional PA gill net
}

\author{
SHU Aiyan ${ }^{1,2}$, ZHANG Min ${ }^{1}$, YU Wenwen ${ }^{2}$, WANG Yue ${ }^{1,2}$, \\ SHI Jiangao ${ }^{2}$, WANG Lei ${ }^{2}$, MIN Minghua ${ }^{2}$ \\ (1. College of Marine Sciences, Shanghai Ocean University, Shanghai 201306, China ;
}

2. East China Sea Fisheries Research Institute, Chinese Academy of Fishery Sciences, Shanghai 200090, China)

\begin{abstract}
With the development of fishery economy, fishing gear materials, such as cotton, which are generally biodegradable, have been replaced by synthetic materials, such as polyethylene ( PE), polypropylene and polyamide (PA), which are difficult to decompose. Synthetic fiber materials exhibit the advantages of high strength, wear resistance and corrosion resistance. Currently used fishing net materials can be classified into PA, PE and polyester, among which PA is the most commonly used and has been used for the longest time. However, fishing nets made from synthetic fibers, such as PA, are not able to degrade in marine environment for decades. When they are lost or abandoned at sea, they will continue to trap fish and other animals, becoming "ghost fishing” gears. Fish and other marine organisms trapped in the abandoned fishing nets will eventually die and become baits to lure other creatures, forming a vicious circle. To conserve the marine environment and mitigate the threats of "white pollution" and "ghost fishing", the use of environment-friendly degradable materials instead of conventional materials has become one of the major innovations in the sustainable development of modern fisheries. In this study, we assessed the physical performance of monofilaments made from a biodegradable resin, polylactic acid ( PLA), in the laboratory, and compared and analyzed the fishing efficiency of gill nets made of PLA monofilaments and conventional PA monofilaments in sea trials conducted on Langya Island from September to October 2019. Results showed that the biodegradable PLA gill net captured 75. 0\% less Portunus trituberculatus but $90.0 \%$ more Pneumatophorus japonicus than PA gill net. The total catch number by PLA gill net was slightly lower than that by PA gill net, and the fishing efficiency of PA gill net was approximately $60.0 \%$ higher than that of PLA gill net. Moreover, mechanical tensile tests showed that the mesh breaking strength of the two gill nets was both significantly reduced after the fishing operation. In addition, PLA meshes were more vulnerable to damage than conventional PA gill net due to the poor toughness and lack of elasticity and flexibility of PLA monofilaments. At the same time, the microscope picture showed that the damage of PA gill net appeared in the middle of the mesh, while PLA gill net in the knot. Furthermore, the breaking strength of PLA
\end{abstract}

Received date: $2020-08-20$

Foundation item: This work was financially supported by the National Natural Science Foundation of China ( No. 31872611 , No.31972844), Taishan Talents Leadership Talent Project (No. 2018RPNT-TSYC-001) and the Central Public-interest Scientific Institution Basal Research Fund (No. 2019CY0304)

Author introduction: SHU Aiyan, female, master's degree in reading, major in biodegradable materials for fishing. E-mail : aiyanshu0219@163.com

Corresponding author: ZHANG Min, professor, E-mail: mzhang@ shou. edu. cn; SHI Jiangao, researcher, E-mail: jiangaoshi666@163.com 
monofilaments was significantly lower than that of PA, so PLA gill net meshes were more easily to be broken. Although PLA gill net is not as efficient as PA gill net in terms of fishing performance, it exhibits a potential advantage in reducing "ghost fishing” and plastic pollution in the ocean, so the usage of PLA gill net can be extended with improvement on strength performance.

Keywords : degradation; gill net; polylactic acid ( PLA); polyamide ( PA ) ; monofilament; physical performance; fishing efficiency; fishing gear materials

\section{CLC number: S 972.3 Document code: A}

High-quality, light-weight, low-cost and highperformance polymer materials have been widely used in all industries and many aspects of our lives because of their powerful functions and practicability. However, “white pollution” caused by the non-degradable conventional polymer materials has seriously threatened the marine ecological environment and has elicited widespread attention $^{[1-3]}$. Fishing nets made from synthetic fibers, such as polyethylene ( $\mathrm{PE}$ ) and polyamide (PA), are not able to degrade even after decades of exposure to seawater environment ${ }^{[4-7]}$. When these nets are lost or abandoned at sea, they will continue to trap fish and other animals, becoming " ghost fishing" gears. PA exhibits excellent strength, wear resistance and corrosion resistance; it is also easy to process $^{[8]}$. Thus, PA is widely used in the field of fishery. Nylon fishing nets, also called PA fishing nets, are frequently used in drift nets, purse seine, offshore cages and other fishing gears. Fishing gears made of nylon nets exhibit good economic benefits, fishing performance and operating efficiency ${ }^{[9-10]}$. In drift nets manufacturing, PA monofilaments are the most commonly used materials ${ }^{[11]}$. PA fishing nets abandoned at sea will decompose into tiny microplastic particles due to photodegradation and other weather phenomena. Microplastic pollution in oceans has become a global environmental problem $^{[12-15]}$. Given that marine fishery ecoenvironmental protection has been gradually becoming worldwidely concerned, the development and application of degradable materials to fishing gears have elicited increasing attention among researchers $^{[16-18]}$.

Biodegradable polymer materials can be decomposed by microbial enzymes or light under certain conditions $^{[19-20]}$. Polylactic acid (PLA) is a new type of biodegradable material. It is made from raw starch materials that can be extracted from renewable plant resources (e. g. , corn). PLA will eventually decompose into carbon dioxide and water in nature and organisms, and thus, it exerts the minimal negative effect on the ecological environment $^{[21-23]}$. PLA fiber is considered one of the most promising green fibers ${ }^{[24-25]}$. It has continuously received attention from various fields of study in recent years ${ }^{[26-27]}$. Fishing gears made from biodegradable plastic materials, such as PLA, are considered a potential solution for mitigating “ghost fishing” and plastic pollution ${ }^{[28-29]}$. GRIMALDO et al. studied the fishing efficiency of gill nets made from a new biodegradable resin, polybutylene succinate co-adipate-co-terephthalate, relative to that of conventional (nylon) nets; their results generally showed better catch rates for nylon gill nets ${ }^{[30]}$.

In the current study, the physical performance of monofilaments made of PLA were studied in the laboratory and the fishing efficiency of gill nets made of PLA and PA monofilaments was compared on Langya Island from September to October 2019. This study aims to evaluate the physical performance and fishing efficiency of biodegradable PLA monofilament gill nets and provide a reference for the application of new degradable fishing materials.

\section{Materials and methods}

\subsection{Biodegradable PLA}

PLA, also known as polylactide, is a highmolecular-weight polymer obtained from 
polymerization with starch as the primary raw material. PLA was purchased from Total Investment Co. , Ltd. , and PLA monofilaments were prepared through melt spinning. Then $0.2 \mathrm{~mm}$ PLA monofilaments were woven into a PLA gill net through double-knotting. A PA gill net with $0.2 \mathrm{~mm}$ PA monofilaments was also produced through the same method.

\subsection{Experimental gear design}

To assess the fishing performance of biodegradable gill nets, experimental gill nets were manufactured with the same design and dimension requirements as commercial gill nets that target Portunus trituberculatus in the coastal areas of Langya Island, Qingdao. Gill netting was selected for the experiments because it is a common fishing method in China, and nets are frequently lost when using this method. Each gill net was made of double-knotted $0.2 \mathrm{~mm}$ monofilaments, with 140 mm nominal mesh opening size. Each net includes 8 $\times 946$ meshes, and was approximately $50 \mathrm{~m}$ in width and $1 \mathrm{~m}$ in height. The schematic of the biological PLA gill net was shown in Fig. 1. Six biodegradable nets and six conventional nylon nets were used in the fishing trials. One biodegradable net and one conventional nylon net were engaged in operations in the fishing ground every day. The nets were renewed after $24 \mathrm{~h}$, and the catch was counted.

\subsection{Sea trials for evaluating fishing efficiency}

From September to October 2019, gill netting trials were conducted on Langya Island's fishing grounds using one to two commercial fishing vessels. The fishing ground is located near Langya Island, Huangdao District, Qingdao City. It is a common fishing area for ships based on Langya Island. Fishing depth varied from 12 to $18 \mathrm{~m}$. Fishing duration was $24 \mathrm{~h}$.

In September 2019, the fishing performances of six biodegradable PLA gill nets and six conventional PA gill nets, were compared during fishing trials conducted under commercial fishing conditions. The density of gill net materials was similar. Thus, we provided similar buoyancy to both types of gill nets. In particular, to evaluate the fishing efficiency of PA and PLA gill nets, we used the method of YANG et al. to compare the collected data of two gill nets ${ }^{[31]}$. The calculation method for fishing efficiency is as follows :

$$
E_{i}=\frac{w_{i}}{h_{i}}
$$

Where $E_{i}$ is the fishing efficiency of the $i$-th netting, $w_{i}$ is the fishing yield of the $i$-th netting $(\mathrm{kg})$, and $h_{i}$ is the duration of the $i$-th netting operation $(\mathrm{h})$.

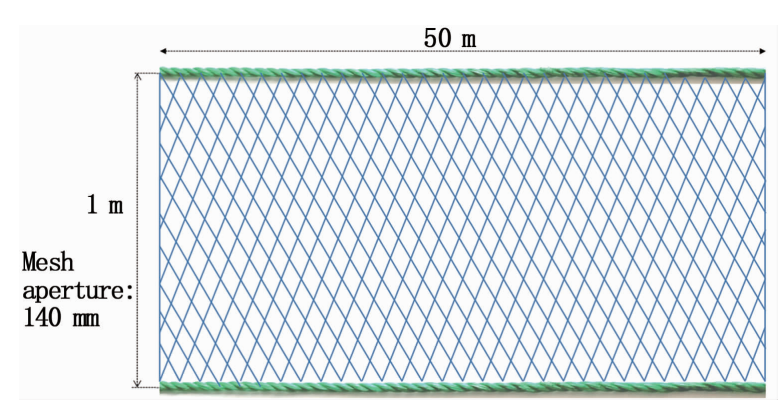

Fig. 1 Schematic diagram of biodegradable PLA gill net

\subsection{Tensile strength tests}

To determine and compare the physical properties of biodegradable PLA and conventional PA monofilaments and their gill nets, their breaking strength (tensile strength at break) and elongation at break were measured. The measurements were conducted in compliance with GB/T 21292-2007 using the universal testing machine Instron 4466 (USA) in tensile mode (i. e. , clamping distance is $100 \mathrm{~mm}$ and tensile speed is $100 \mathrm{~mm} \cdot \min ^{-1}$ ). Tensile strength tests were performed on the biodegradable and nylon gill nets before and after the fishing operation.

\subsection{Gill net damage assessment}

We evaluated the degree of damage by calculating the number of broken meshes of each gill net and using a microscope to examine each gill net sample. The degree of damage of each gill net was analyzed. The results were presented as percentages of the total quantity of knots from the sample. 


\subsection{Wear test}

The wear test used the TABER $^{\circledR}$ Model 5750 reciprocating linear abrader (USA). The test machine stroke was $75 \mathrm{~mm}$, the wear test speed was 60 times per minute, and the sandstone model used for the wear test was $\mathrm{H}-18^{[32]}$. The wear test was conducted under two conditions: dry friction and water lubrication ( tap water was used as the lubricating medium). Before the wear test, the abrasive body of the H-18 sandstone should be polished using a metallographic sandpaper of the same model. Then, the H-18 sandstone was washed with tap water and dried for later use. During the wear test, certain pressure loads (2.5 N and 5.0 N) must be added to ensure that the abrasive body was pressed tightly to the compound fishing PLA and PA monofilament test samples.

\section{Results}

\section{1 Physical performance of monofilaments}

The mechanical properties of PLA and PA monofilaments were studied. PLA and PA monofilaments are mostly used as knots and woven into gill nets in fisheries. Thus, we tested the knotting strength of the monofilaments (Fig. 2 ). The linear density of PLA and PA monofilaments was 44 tex and 57 tex, respectively. Under dry condition, the corresponding knotting strength of PLA and PA monofilaments was $2.5 \mathrm{cN} \cdot \mathrm{dtex}^{-1}$ and 3. $0 \mathrm{cN} \cdot \operatorname{dtex}^{-1}$ respectively. Under wet condition, the knotting strength of PLA and PA monofilaments was $2.3 \mathrm{cN} \cdot \mathrm{dtex}^{-1}$ and $2.9 \mathrm{cN} \cdot$ $\mathrm{dtex}^{-1}$ respectively. Compared with the knotting strength of PLA and PA monofilaments under dry condition, the knotting strength under wet condition decreased by $8.0 \%$ and $3.3 \%$, respectively, and the decrease in the mechanical strength of PLA monofilaments was greater than that of PA monofilaments.

\subsection{Wear resistance of PLA and PA monofilaments}

Under the same friction conditions, a sample was rubbed sufficiently until it broke. The wear resistances of PLA and PA monofilaments were studied.

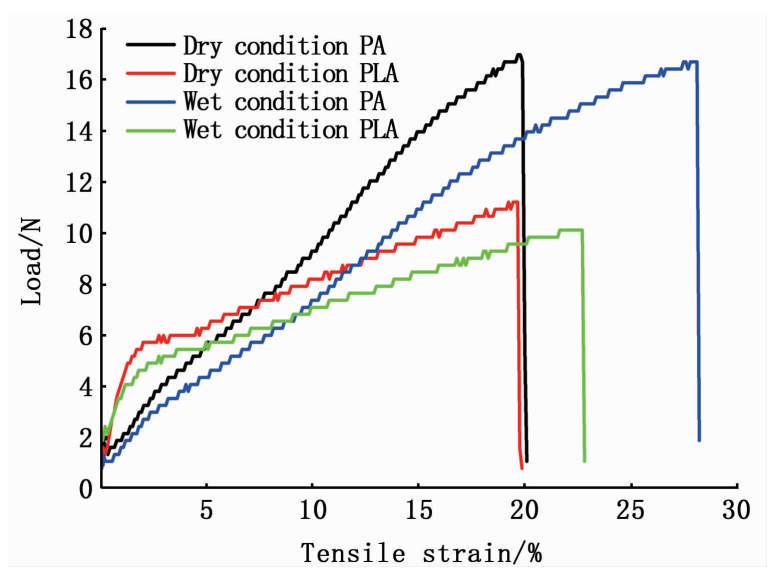

Fig. 2 Mechanical properties of PA and PLA monofilaments under dry and wet conditions

Tab. 1 presented the test results of wear times of PLA and PA monofilaments. As shown in the table, wear resistance under water-lubricated friction was better than that under dry friction condition under the same pressure load. As pressure load increased, the wear times of the monofilament test sample decreased. Friction condition exerted a significant impact on wear times. Simultaneously, the wear resistance of PLA monofilaments was better under dry friction condition. By contrast, the wear resistance of PA monofilaments was better under water lubrication.

Tab. 1 Comparison of wear times for PLA and PA monofilaments

\begin{tabular}{cccc}
\hline \multirow{2}{*}{ Friction condition } & Monofilament & \multicolumn{2}{c}{$\begin{array}{c}\text { Wear times under } \\
\text { different pressure loads }\end{array}$} \\
\cline { 3 - 4 } & & $2.5 \mathrm{~N}$ & $5.0 \mathrm{~N}$ \\
\hline \multirow{2}{*}{ Dry friction } & PLA & 18 & 9 \\
& PA & 6 & 2 \\
Water lubrication & PLA & 40 & 26 \\
& PA & 147 & 84 \\
\hline
\end{tabular}

\subsection{Catch statistics}

Two types of experimental gill nets were engaged in operations for six times in the fishing ground. The weight and length of all species caught by the two types of gill nets were measured. The catch was mostly composed of P. trituberculatus and 
Pneumatophorus japonicus, with very few Parthenope validus. However, the number of Parthenope validus was too small (i. e., less than five), and thus it was not included in the study. A total of 44 were caught using 12 gill nets. Among which, 21 were caught by PLA gill nets and 23 by PA gill nets (Tab. 2).

Tab. 2 Catch statistics of PLA and PA gill nets

\begin{tabular}{ccccc}
\hline Set ID & $\begin{array}{c}\text { Minimum } \\
\text { weight/g }\end{array}$ & $\begin{array}{c}\text { Maximum } \\
\text { weight/g }\end{array}$ & $\begin{array}{c}\text { Number of } \\
\text { catch by } \\
\text { PLA gill net }\end{array}$ & $\begin{array}{c}\text { Number of } \\
\text { catch by PA } \\
\text { gill net }\end{array}$ \\
\hline 1 & 11.84 & 67.84 & 13 & 2 \\
2 & 78.68 & 363.34 & 5 & 3 \\
3 & 11.52 & 156.54 & 0 & 9 \\
4 & 27.20 & 367.47 & 0 & 5 \\
5 & 281.12 & 316.41 & 1 & 1 \\
6 & 22.48 & 117.45 & 2 & 3 \\
\hline
\end{tabular}

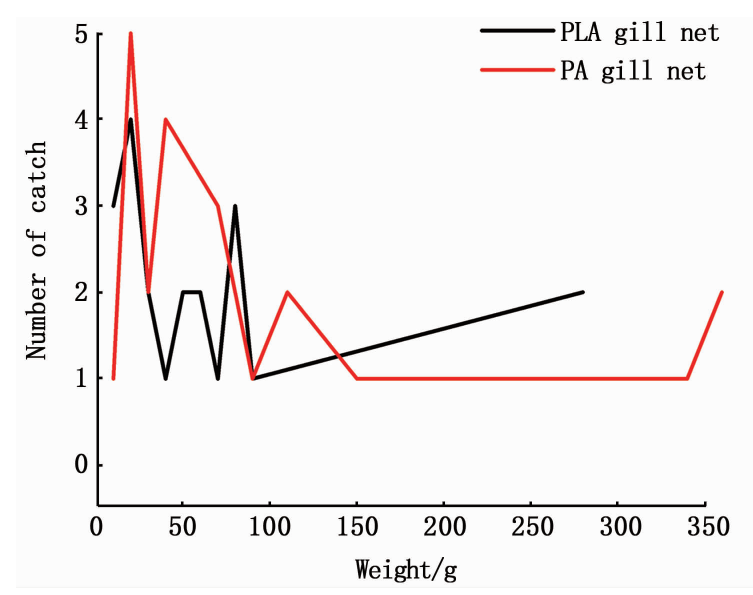

Fig. 3 Statistics of different weight intervals by PLA and PA gill nets

As indicated in Fig. 3, PLA gill net catch ranged from $10 \mathrm{~g}$ to $280 \mathrm{~g}$, and $\mathrm{PA}$ gill net catch ranged from $10 \mathrm{~g}$ to $360 \mathrm{~g}$. The minimum weight of fish caught by PA gill nets was $18 \mathrm{~g}$ and the maximum was $367 \mathrm{~g}$; the minimum weight of fish caught by PLA gill nets was $12 \mathrm{~g}$, and the quantity was more than that by PA gill nets, the maximum was $284 \mathrm{~g}$. The number of P. trituberculatus caught by conventional PA gill nets was slightly higher than that by biodegradable PLA gill nets (16 versus 4 ). The case with the most important bycatch species was the opposite ( 1 versus 10 P. japonicus). A slight difference was observed in the overall number of total catch between the PLA and PA nets (21 versus 23 ).

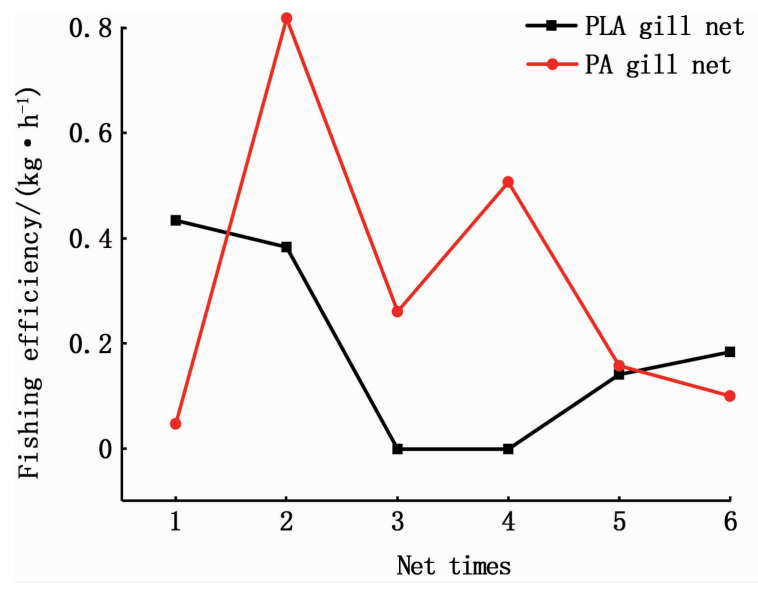

Fig. 4 Fishing efficiency of PLA and PA gill nets

Then, fishing efficiency was calculated (Fig. $4)$. The results showed that the average fishing efficiency of PLA gill nets was $0.20 \mathrm{~kg} \cdot \mathrm{h}^{-1}$, and that of PA gill nets was $0.32 \mathrm{~kg} \cdot \mathrm{h}^{-1}$. The fishing efficiency of PA gill nets was $60 \%$ higher than that of PLA gill nets. The number of gill nets used in this experiment was limited, and the catch was relatively few. We will continue the fishing experiment with the same experimental materials in 2021 and combine the subsequent catch data for statistical significance analysis, and summarize it in a follow-up research paper.

\subsection{Gill net damage}

Tensile strength measurements performed before and after the fishing experiment showed that the breaking strength of PLA gill nets decreased by $8.7 \%$ (from $12.7 \mathrm{~N}$ to $11.6 \mathrm{~N}$ ) and that of $\mathrm{PA}$ gill nets decreased by $4.0 \%$ (from $18.5 \mathrm{~N}$ to $17.7 \mathrm{~N}$ ).

Tab.3 Tensile strength and broken percentage of PLA and PA gill nets

\begin{tabular}{ccccc}
\hline \multirow{2}{*}{ Material } & \multicolumn{2}{c}{ Tensile strength/N } & Reduction/ & $\begin{array}{c}\text { Broken } \\
\text { nercentage/\% }\end{array}$ \\
\cline { 2 - 3 } & New & Worn & & percent \\
\hline PLA & 12.7 & 11.6 & 8.7 & 26 \\
PA & 18.5 & 17.7 & 4.0 & 12 \\
\hline
\end{tabular}

PLA gill nets had more severely damaged or broken knots (26\%), and PA gill nets were damaged by $12 \%$. PLA gill nets were more damaged than PA gill nets (Tab. 3). At the same 
time, the microscope picture showed that the damage of PA gill net in the middle of the mesh, and for PLA gill net in the knot. The damage in the knots was apparently caused by normal use and wear throughout the fishing season (i. e., abrasion in the hauling machine, friction due to contact with hard surfaces when gill nets were operated on deck), which turned the smooth surface of the materials ( when new) into rough after fishing trials. Microscopic pictures showed that damage to PLA gill nets was due to the breakage of an entire monofilament at the knot. Meanwhile, damage to PA gill nets mostly manifested as damage to the monofilaments (Fig. 5).

\section{Discussions}

The physical performance results of PLA and

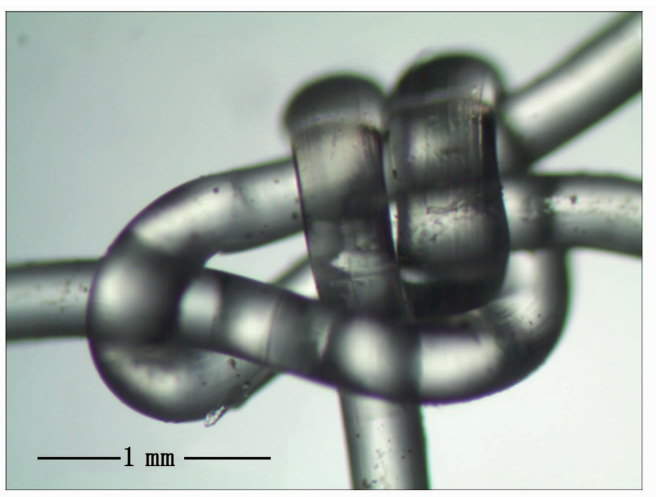

(a) PA-before

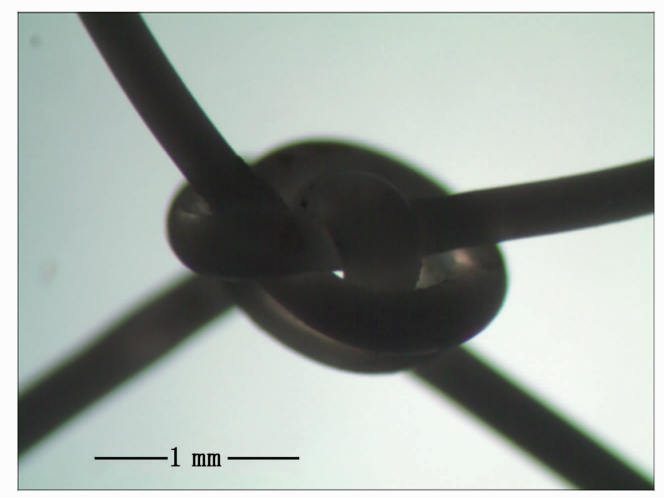

(c) PLA-before
PA monofilaments showed that compared with the knotting strength of PLA and PA monofilaments under dry condition, knotting strength under wet condition decreased by $8.0 \%$ and $3.3 \%$, respectively. The samples exhibited lower knotting strength under wet condition than under dry condition $^{[33]}$. This result was as expected because water acted as a plasticizer that reduced entanglement and bonding between molecular chains, increasing their volume and mobility. Consequently, the absorbed water decreased tensile modulus, but increased elongation at break. The knotting strength of PLA monofilaments decreased more than that of PA monofilaments, indicating that PLA monofilaments absorbed water more easily.

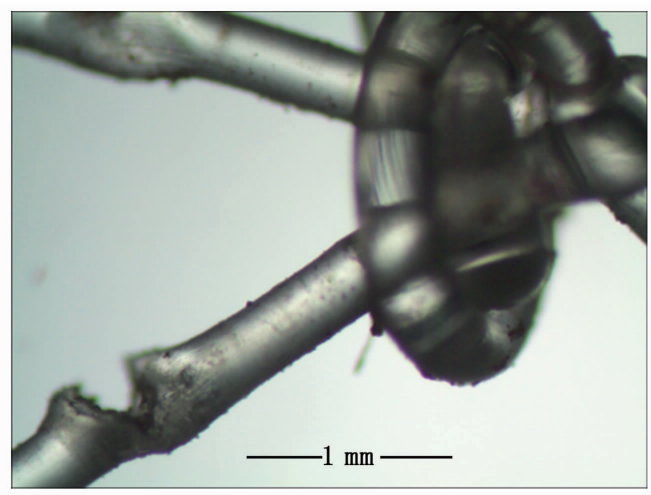

(b) PA-after

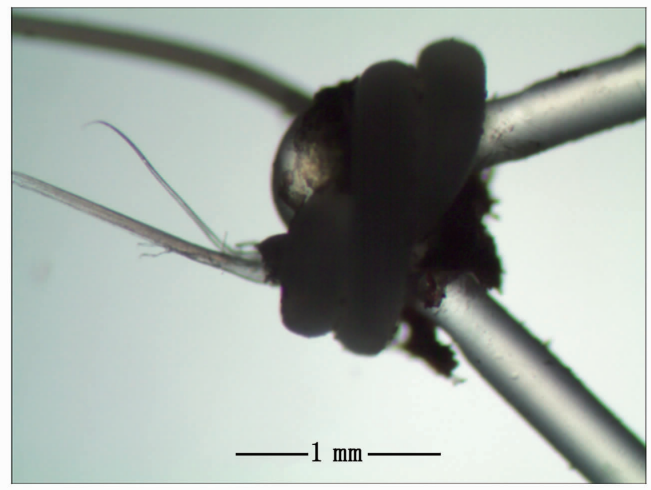

(d) PLA-after

Fig. 5 Damage degree of PLA and PA gill nets before and after the experiment 
The wear resistance results of PLA and PA monofilaments showed that the wear resistance of PLA monofilaments was greater under dry friction conditions, while the wear resistance of PA monofilaments was better under water lubrication. This finding may be attributed to the absorption of more water on PLA surface ${ }^{[34]}$. Water diffused into the amorphous regions of PLA, leading to plasticization, swelling and softening, and consequently a reduction in hardness and poor wear resistance.

The biodegradable PLA gill nets caught $75.0 \%$ less P. trituberculatus than PA gill nets, PLA gill nets caught $90.0 \%$ more $P$. japonicus than PA gill nets, and the total catch of PLA gill nets was slightly lower than that of PA gill nets. The fishing efficiency of PA gill nets was $60.0 \%$ higher than that of PLA gill nets. This finding was consistent with the results of the physical performance and wear resistance tests of the monofilaments. PLA monofilaments exhibited a greater decrease in knotting strength under wet condition. Thus, PLA monofilaments were more likely to absorb water, resulting in reduced hardness and poor wear resistance. Therefore, the fishing efficiency of PLA gill net was evidently inferior to that of PA gill net. The results of sea trials indicated that further study of biodegradable materials should focus on the improvement of fishing efficiency. The results generally showed better catch rates by $\mathrm{PA}$ gill nets than by PLA gill nets, particularly for large $P$. trituberculatus, despite of having similar mesh sizes. The physical properties of gill net material variated with time and might have affected its fishing efficiency. Tensile strength measurements before and after the fishing experiments showed that the fracture strength of both gill nets was significantly reduced. Compared with PA gill nets, PLA gill nets were damaged more, indicating that the mechanical properties of PLA material still require considerable improvement. When new, the strength of both types of nets was remarkably similar. By the end of the fishing season, the reduction in tensile strength and the loss of elasticity can explain the major difference in catch efficiency between PA and PLA gill nets, particularly for large P. trituberculatus. CHEN et al. studied the degradability of polylactic acid/starch composite materials in seawater environment and suggested that biological degradation was probably a cause of tensile strength and elasticity reduction of biodegradable gill nets ${ }^{[35]}$. On the basis of our experience, we can not distinguish the degree of strength reduction caused by biodegradation from the degree of strength and elasticity reduction caused by use and wear. Although PLA gill nets are not as efficient as PA gill nets, they are effective in reducing marine "ghost fishing" and plastic pollution, providing a reference for alleviating these major fishery environmental problems.

Notably, if biodegradation is combined with daily use and wear of the material, then the degradation process may be somehow accelerated $^{[30]}$. Nylon gill nets are well-documented to be highly resistant to degradation, but they do eventually lose their capability for "ghost fishing" depending on the seafloor conditions ( e. g. , substrate type, sea temperature, and light condition $)^{[36-38]}$. Furthermore, nylon gill nets do not disappear entirely. They just break into smaller plastic particles, commonly known as “microplastics", which may continue to disturb important processes in marine ecosystems ${ }^{[39-40]}$. In contrast to conventional nylon gill nets, if biodegradable gill nets get lost at sea, bacteria, algae and fungi will more rapidly degrade the material into carbon dioxide, methane and water, and therefore, they will have no negative impact on marine ecosystems. KIM et al. reported that biodegradable gill nets started to degrade after two years of being immersed in seawater ${ }^{[41]}$. However, this conclusion was based on a degradation experiment with monofilament samples immersed in seawater, and thus, the samples were not affected by physical damage from daily use and wear. Determining how fast a biodegradable gill net can lose its "ghost fishing" capability depends 
considerably on the age of the net when it is lost and how much it has been used. In fishery, degradation materials and antifouling materials are collectively referred to as functional materials ${ }^{[42-43]}$. The research and development of new functional materials for fishing can gradually solve the "ghost fishing" problem of fishing gears and the antifouling problem of aquaculture netting ( such as the netting of deep-sea cages, deep-sea enclosures, etc. ), so as to promote the sustainable development and modern construction of modern fishery ${ }^{[44-45]}$. China's modern fishery has a bright future, but there is still a long way to go for the work of functional novel materials for fishery.

\section{References :}

[1] RUAN G, FENG S S. Preparation and characterization of poly ( lactic acid)-poly (ethylene glycol)-poly (lactic acid) ( PLA-PEG-PLA) microspheres for controlled release of paclitaxel $[\mathrm{J}]$. Biomaterials, 2003, 24(27) : $5037-5044$.

[2] MA H Y, SHAO X Q, MA H J, et al. Research and development of the large diameter biodegradable polymer monofilament $[\mathrm{J}]$. China Textile Leader, 2014, (4) : $54-57$.

[3] LUSHER A, HOLLMAN P, MENDOZA-HILL J. Microplastics in fisheries and aquaculture: Status of knowledge on their occurrence and implications for aquatic organisms and food safety: Abstract [J]. FAO Fisheries \& Aquaculture Technical Paper, $2017,(615): 4-5$.

[4] ZHOU A Z, ZHANG Y, YU Y F, et al. Experimental research on trawl performance of braided polyethylene netting twine replacing common polyethylene twisting [J]. Marine Fisheries, 2013, 35(1) : 95 - 101.

[5] YU W W, SHI J G, CHEN X X, et al. The mechanical properties and dynamic mechanical behavior of MHMWPE/iPP/EPDM fishery monofilaments $[\mathrm{J}]$. Journal of Fisheries of China, 2017, $41(3): 473-479$.

[6] YU W W , SHI J G, CHEN X X, et al. Study on the suitability for fishing fibers based on dynamic mechanical analysis $[\mathrm{J}]$. Marine Fisheries, 2016, $38(5): 533-539$.

[7] SHI J G, WANG L M. Comparative study of tensile mechanic performance of ultra high molecular weight polyethylene and high density polyethylene netting twines $[\mathrm{J}]$. Periodical of Ocean University of China (Natural Science Edition), 2004, (3) : 381 - 388.

[8] YU W W, LIU Y L, SHI J G, et al. UV aging behavior of nylon nets $[\mathrm{J}]$. Fishery Information \& Strategy, 2018, 33(4) : $267-271$.

[9] SHI J G, ZHOU X J, SHEN M. Agriculture technology of deep-offshore cage $[\mathrm{M}]$. Beijing: Ocean Press, 2019: $1-330$.

[10 ] SHI J G, WANG L M, CHEN X L, et al. Progress on research of novel synthetic fiber materials for fishing $[\mathrm{J}]$. Modern Fisheries Information, 2008, $23(5): 7-10+13$.

[11] SUN M C, SHI J G, XU C C, et al. Fishing gear materials and technology $[\mathrm{M}]$. Beijing: China Agriculture Press, 2009:1 - 41 .

[12] ZHOU Q, ZHANG H B, LI Y, et al. Progress on microplastics pollution and its ecological effect in the coastal environment $[\mathrm{J}]$. Chinese Bulletin, 2015, $60(33)$ : $3210-3220$.

[13] ZHANG H B, ZHOU Q, ZHOU Y, et al. Raising concern about microplastics pollution in coastal and marine environment and strengthening scientific researches on pollution prevention and management [J]. Bulletin of Chinese Academy of Sciences, 2016, $31(10)$ : $1182-1189$.

[14] YU H Q, LIANG D J, TAN Q Y, et al. The issues of marine litter and microplastics pollution and relevant international process $[\mathrm{J}]$. World Environment, 2018(2): $50-53$.

[15] LONG Z X, YU X G, JIN X L, et al. Raising concern about microplastics pollution in coastal and marine environment and strengthening scientific researches on pollution prevention and management [J]. Journal of Applied Oceanography, 2017, 36 (4) : $586-596$.

[16] MIN M H, HUANG H L, SHI J G, et al. Research and tendency of fishery polyethylene fiber $[\mathrm{J}]$. Marine Fisheries, 2014, 36(1) : 90 - 96.

[17] CHEN X L, WANG L M, SHI J G, et al. Research advances on biodegradable polymer in aqueous environment $[\mathrm{J}]$. Marine Fisheries, 2009, 31 (1): 106 - 112

[18 ] CHEN X L, SHI J G, LIU Y L, et al. Thermal and aging resistance properties of cage frame materials high density polyethylene/barium sulfate nonocomposites $[\mathrm{J}]$. Marine Fisheries, 2012, 34 (1) : $96-101$. 
[19] HU J P, XING D, GUO M H. Research process and prospect in plant fiber reinforced polylactide acid biodegradable composites $[\mathrm{J}]$. Journal of Southwest Forestry University, 2020, 40(3) : $180-188$.

[20 ] CHEN X L, SHI J G, SHI H, et al. Degradability of polycaprolactone in seawater environment $[\mathrm{J}]$. Marine Fisheries, 2010, 32(1) : $82-88$.

[21] LEE H, AHN S, CHOI H, et al. Fabrication, characterization, and in vitro biological activities of melt-electrospun PLA micro/nanofibers for bone tissue regeneration $[\mathrm{J}]$. Journal of Materials Chemistry B , 2013, 3(1) : $3670-3677$.

[22] YUE Z, YOU Z, YANG Q, et al. Molecular structure matters: PEG-b-PLA nanoparticles with hydrophilicity and deformability demonstrate their advantages for high-performance delivery of anticancer drugs $[\mathrm{J}]$. Journal of Materials Chemistry B, $2013,26(1): 3239-3247$.

[23] HU Q, GAO X, GU G, et al. Glioma therapy using tumor homing and penetrating peptide-functionalized PEG-PLA nanoparticles loaded with paclitaxel $[\mathrm{J}]$. Biomaterials, 2013, 34(22) : 5640 - 5650.

[24] ZHANG W, CHEN L, ZHANG Y. Surprising shape memory effect of polylactide resulted from toughening by polyamide elastomer $[\mathrm{J}]$. Polymer, 2009, 50 (5) : $1311-1315$.

[25] LIAO K R, QUAN D P, GAO J W, et al. The mechanical properties and degradation behavior in vitro of PLLA/PDLLA blends $[\mathrm{J}]$. Acta Scientiarum Naturalium Universitatis Sunyatseni, 2002, (1) : 51 -54 .

[26] SAJJAD S, MiChel A H, HONGBO L, et al. Poly ( lactic acid) crystallization $[\mathrm{J}]$. Progress in Polymer Science, 2012, 37(12) : 1657 - 1677.

[27] PAN W J, BAI Z H, SU T T, et al. The modification of biodegradable plastic polylactic acid (PLA) $[\mathrm{J}]$. Applied Chemical Industry, 2017, 46 (5) : 977 981.

[28 ] BROWN J, MACFADYEN G. Ghost fishing in European waters: Impacts and management responses $[\mathrm{J}]$. Marine Policy, 2007, 31 (4) : 488 - 504.

[29] GILMAN E. Status of international monitoring and management of abandoned, lost and discarded fishing gear and ghost fishing $[\mathrm{J}]$. Marine Policy, $2015(60): 225-239$.

[30 ] GRIMALDO E, HERRMANN B, VOLLSTAD J, et al. Fishing efficiency of biodegradable PBSAT gillnets and conventional nylon gillnets used in
Norwegian cod (Gadus morhua) and saithe (Pollachius virens) fisheries [ $\mathrm{J}]$. ICES Journal of Marine Science, 2018, 75(6) : 2245 - 2256.

[31 ] YANG J L, HUANG H L, WU Y, et al. Impact factor analysis of fishing efficiency of Trachurus murphyi in abnormal marine environment $[\mathrm{J}]$. Marine Fisheries, 2016, 38(6) : 588 - 596.

[32] SHI J G, CHEN X L, LIU Y L, et al. Comparative study on abrasive resistance of compound fishing PP/ $\mathrm{PA}$ and common PP monofilaments $[\mathrm{J}]$. Marine Fisheries, 2011, 33(3) : $335-345$.

[33] MELVIN I, KOHAN. Nylon plastics handbook [M]. New York: Hanser Gardner Publications, 1995.

[34] SRINATH G, GNANAMOORTHY R. Sliding wear performance of polyamide 6-clay nanocomposites in water $[\mathrm{J}]$. Composites Science \& Technology, $2007,67(3-4): 399-405$.

[35 ] CHEN X L, SHI J G, WANG L, et al. Degradability of poly (lactic-acid)/starch composite in seawater [J]. Marine Fisheries, 2009, 31(4) : 420 - 425.

[36 ] NAKASHIMA T, MATSUOKA T. Ghost fishing ability decreasing over time for lost bottom-gillnet and estimation of total number of mortality $[\mathrm{J}]$. Nippon Suisan Gakkaishi, 2004, 70 ( 5 ) : 728 737.

[37 ] HUMBORSTAD O B, LOKKEBORG S, HAREIDE $\mathrm{N} \mathrm{R}$, et al. Catches of Greenland halibut (Reinhardtius hippoglossoides) in deep-water ghost fishing gill nets on the Norwegian continental slope $[\mathrm{J}]$. Fisheries Research, 2003, 64 (2-3): 163 170 .

[38 ] PHAM C K, RAMIREZ-LLODRA E, ALT CLAUDIA H $\mathrm{S}$, et al. Marine litter distribution and density in European seas, from the shelves to deep basins $[\mathrm{J}]$. PLoS One, 2014, 9(4) : e95839.

[39] DESFORGES J P W, GALBRAITH M, ROSS P S. Ingestion of microplastics by zooplankton in the Northeast Pacific Ocean $[\mathrm{J}]$. Archives of Environmental Contamination and Toxicology, 2015, (69) : $320-330$.

[40] CHAE Y, AN J Y. Effects of micro- and nanoplastics on aquatic ecosystems: Current research trends and perspectives $[\mathrm{J}]$. Marine Pollution Bulletin, 2017, (124): $624-632$.

[41] KIM S, PARK S, LEE K. Fishing performance of an Octopus minor net pot made of biodegradable twines [J]. Turkish Journal of Fisheries and Aquatic Sciences, 2014, 14: $21-30$. 
[42] SHI J G, YU W W, ZHAO K, et al. Progress on research of antifouling technology of offshore cage netting $[\mathrm{J}]$. Journal of Fisheries of China, 2020, doi : 10. 11964/jfc. 20200512274.

[43] SHI J G. Agriculture technology of deep-sea ecological enclosure [M]. Beijing: Ocean Press, 2019: 77 222.
[44] SHI J G, YU W W, LU B C. Development status and prospect of Chinese deep-sea cage $[\mathrm{J}]$. Journal of Fisheries of China, 2020. Doi: 10. 11964/jfc. 2020062314.

[45] Shi J G, Zhou X J, SHEN M. Agriculture technology of deep-offshore cage $[\mathrm{M}]$. Beijing: Ocean Press, 2019: $1-330$. 


\title{
可生物降解 PLA 刺网与传统 PA 刺网的 物理性能和捕捞效率的比较分析
}

\author{
舒爱艳 ${ }^{1,2}$, 张 敏 $^{1}$, 余雯雯 ${ }^{2}$, 王 越 ${ }^{1,2}$, \\ 石建高 $^{2}$ ，王 磊 ${ }^{2}$, 闵明华 ${ }^{2}$ \\ (1. 上海海洋大学海洋科学学院, 上海 201306; 2. 中国水产科学研究院东海水产研究所, 上海 200090)
}

\begin{abstract}
摘 要: 为了保护海洋生态环境, 减少遗弃的不可降解渔网造成的“白色污染”及“幽灵捕捞” 的危害, 研究开 发环保可降解渔用材料已成为我国现代渔业可持续发展的重大问题之一。以可生物降解树脂聚乳酸 (PLA) 制成的刺网为研究对象, 研究了 PLA 单丝的物理性能, 并于 2019 年 9 月至 10 月在琅㑚岛渔场通过捕拹实验, 对比分析了 PLA 刺网和常规聚酰胺 (PA) 刺网的物理性能和捕捞效率。结果显示, 可生物降解的 PLA 刺网对 于梭子蟹 (Portunus trituberculatus) 的捕获量比 PA 刺网少 75.0\%, PLA 刺网对于鲐鱼 (Pneumatophorus japonicus) 的捕获量比 PA 刺网多 $90.0 \%$ 。PLA 刺网的捕捞总量略低于 PA 刺网, PA 刺网的捕捞效率比 PLA 刺网高约 $60.0 \%$ 。 PLA 和 PA 刺网捕捞实验前后的拉伸力学性能结果表明, 这两种刺网的网目断裂强力均明 显降低。此外, 与传统 PA 刺网相比, PLA 网目破损程度更高, 这是由于 PLA 单丝的㓞性较差, 缺少弹性以及 柔性, 断裂强度明显低于 PA 单丝, 因此 PLA 刺网网目更容易断裂。显微镜照片显示, PA 刺网一般从网目中 间破损, 而 PLA 刺网破损情况多发生在结节处。尽管 PLA 刺网捕捞效率不如 PA 刺网, 但其在减少海上“幽 灵捕捞” 和塑料污染方面具有潜在优势。
\end{abstract}

关键词: 降解; 刺网; 聚乳酸; 聚酰胺; 单丝; 物理性能; 捕捞效率; 渔具材料

中图分类号: S972.3 文献标志码: A

收稿日期: $2020-08-20$

基金项目: 国家自然科学基金(31872611,31972844); 泰山英才领军人才项目 (2018RPNT-TSYC-001); 中国水产科 学研究院基本科研业务费(2019CY0304)

作者简介: 舒爱艳,女, 硕士研究生, 研究方向: 可降解渔用材料。E-mail: aiyanshu0219@163.com

通信作者：张 敏,教授,E-mail: mzhang@ shou. edu. cn; 石建高, 研究员,E-mail: jiangaoshi666@ 163.com 